DOI: https://doi.org/10.4796o/2303-7431.24.2020.203

UDK: 791.2

Pregledni članak

Primljen 24. XI. 2020.

Prihvaćen 20. IV. 2021.

Jelena Grgić

Zagreb

jelena.grgic@email.ht.hr

\title{
NOVI HOLLYWOOD - SOCIOPOLITIČKI KONTEKST I ŽANROVSKI ASPEKT
}

\section{Sažetak}

Rad obuhvaća pregled redatelja i filmova Novoga Hollywooda te društveno-politički kontekst i mijene u američkome načinu života, koje su prethodile nastanku tzv. blockbustera, odnosno novožanrovskih filmova. U radu će biti riječ o svježem autorskom pristupu žanrovskomu filmu generacije školovanih redatelja koji će u svojim djelima uspješno revalorizirati žanr, a od kojih će nekolicina marketinškom stručnošću osigurati nastavke svojih filmova u (i danas vrlo popularnomu) obliku franšize. Kroz analizu opusa novoholivudskih redatelja mlađe, a dijelom i starije, generacije demonstrirat će se njihov odnos prema društvenim i političkim okolnostima, revitalizacija marginaliziranih žanrova kao i stilska obilježja filmova, poput intertekstualnosti, citatnosti, pastiša, hommagea (posvete) itd.

Ključne riječi: Novi Hollywood; blockbuster; hommage; žanr; političko-socijalni kontekst; američka kinematografija

\section{Termin}

Duncan McLean u članku The Evolution of the Term „New Hollywo$o d^{\prime \prime}$ istražuje termin i različite definicije Novoga Hollywooda, poznata i 
pod nazivom holivudska renesansa. Navodi da se pojam Novi Hollywood odnosi na novu generaciju filmaša, novu ciljanu publiku, novi estetski stil i novi društveno-relevantni sadržaj. ${ }^{1}$

Filmolozi i filmski kritičari pretežno se referiraju na dvije generacije filmskih autora koje su zaslužne za holivudsku renesansu. Prvu generaciju čine redatelji rođeni dvadesetih i tridesetih godina prošloga stoljeća, koji su došli u filmsku industriju iz kazališta ili rastuće televizijske industrije: Don Siegel, Robert Altman, Sam Peckinpah, Peter Bogdanovich, Dennis Hopper, Roman Polanski, Arthur Penn, William Friedkin, Francis Ford Coppola itd., a djelovali su uglavnom od sredine šezdesetih do ranih sedamdesetih. Drugu generaciju čine redatelji rođeni četrdesetih godina prošloga stoljeća, polaznici novih filmskih škola (UCLA i NYU): Martin Scorsese, Brian De Palma, George Lucas, Paul Schrader, Terrence Mallick, John Milius, Steven Spielberg (iako nije pohađao filmsku školu), John Carpenter, Walter Hill itd., koji režiraju od ranih sedamdesetih do osamdesetih godina. ${ }^{2}$

Ova generacijska podjela dovodi do zbunjenosti oko pojma Novi Hollywood, odnosno nesuglasica oko statusa prve i druge generacije. Ono što najviše razdvaja ove dvije skupine jest filmska naobrazba mlađega naraštaja i njihovo usmjerenje na blockbustere i eksploatacijske žanrove poput filma strave. Dio kritičara koji želi naglasiti distinktivna obilježja druge, mlađe generacije filmaša dodaje određeni prefiks terminu Novi Hollywood; McLean navodi dva takva primjera - Drugi novi Hollywood (The second New Hollywood) odnosno Novi, novi Hollywood (New New Hollywood). ${ }^{3}$

Usp. Duncan Mclean, „The Evolution of the term 'New Hollywood'“, Macquarie University, (9. X. 2009.), <http://www.researchonline.mq.edu.au/vital/access/manager/Re-

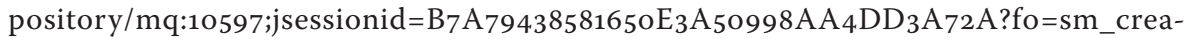
tor\%3A\%22McLean\%2C+Duncan\%22>, (23. X. 2020.).

2 Isto.

3 Isto. 


\section{Sociopolitički kontekst}

Novi je Hollywood termin koji se odnosi na američku kinematografiju s kraja šezdesetih i početka sedamdesetih godina prošloga stoljeća, a usko je vezan za propast vladajućih, megalomanskih filmskih studija i pojavu nezavisnih producenata. Nakon holivudskoga klasičnog doba dvadesetih, tridesetih i ranih četrdesetih godina 20. stoljeća dolazi do smjene holivudskih studijskih sustava i postupne dominacije novih tržišta kabelske televizije i kućnoga videorekordera. Dolaskom konkurentnih medijskih tehnologija i izgradnjom mnogobrojnih multipleks kina transformira se čvrsto integrirano tržište klasičnoga Hollywooda $\mathrm{u}$ fragmentirano (postmoderno), čime se najavljuju velike promjene na području filmske umjetnosti. Filmska djelatnost u ovome razdoblju obuhvaća popratne sadržaje poput filmskih i glazbenih albuma, videokaseta itd.

Filmski kritičar Damir Radić pojavu Novoga Hollywooda stavlja u društveno-umjetnički kontekst šezdesetih godina u SAD-u, pritom navodeći ključna imena filmske novožanrovske struje koja je kategorizirao prema razdoblju njihova najplodnijeg stvaralaštva:

Kroz 6o-e godine izuzetno je aktivna američka filmska underground produkcija (Anger, Warhol) američka underground rock scena (Velvet Underground, npr.) a tim senzibilitetom (eksplicitnije ili implicitnije) odlikuju se i neki stariji režiseri koji upravo na prijelazu iz 6o-ih u 70-e dostižu svoj zenit - Don Siegel, Richard Aldrich, zatim Cormanova generacija - Sam Peckinpah i Robert Altman, i nešto mlađi Stanly Kubrick i nešto stariji te iznimno utjecajni Arthur Penn. Od prve novohollywoodske generacije tu su još Burtel (također jedno vrijeme Cormanov štićenik), Kaufman, De Palma, Friedkin, Spilberg i drugi, a oko sredine 70-ih srodnim temama javljaju se predstavnici druge hollywoodske generacije - Walter Hill i John Carpenter. ${ }^{4}$

Društveno-politički kontekst kasnih šezdesetih i ranih sedamdesetih može se rezimirati kao skup političkih i generacijskih srazova. Mnoge pokrete koji su redefinirali društvenu strukturu, poput pokreta za

DAmir RADIĆ, „Martin Scorsese“, Kinoteka, Filmoteka 16, Zagreb, god.II. (199o.) br. 23., str. 16. 
građanska prava, feminizma, prava homoseksualaca, mirovnoga pokreta i hipi generacije, podržavaju novi naraštaji koji spremnije iskazuju bunt protiv društvenih nepravilnosti. Osim okrenutosti liberalnijim shvaćanjima i društvenim strukturama, u ovome se razdoblju Amerika suočava s Vijetnamskim ratom, ubojstvima Roberta Kennedyja i Martina Luthera Kinga Jr. (oba 1968.), inflacijom i Watergate skandalom. Vidljivo je da se američka populacija nalazi u razdoblju gospodarstvene, političke i socijalne krize, ali i krize identiteta.

Kriza zahvaća i filmsku industriju koja se suočava s kontroverznim odlukama filmske akademije koja glavnu nagradu dodjeljuje cenzuriranomu Ponoćnom kauboju / Midnight Cowboy (1969.). Zaredali su se filmovi koji su tematizirali nasilje (Divlja horda / Wild Bunch, 1969., Paklena naranča / Clockwork Orange, 1971.) i seksualnost (Posljednji Tango u Parizu / Last Tango in Paris, 1972.), a zahvaljujući utjecaju tinejdžerske publike, jača popularnost akcijskih filmova, poput onih s Clintom Eastwoodom i Charlesom Bronsonom u glavnim ulogama. Šezdesete i sedamdesete godine postaju presudne i za stari studijski sustav; gledateljstvo se brojčano smanjilo, a tržište raslojilo, te su status zvijezda i popularnost žanrova zapali u drugi plan.

Nakon niza filmskih promašaja palicu preuzimaju mlađi novoholivudski producenti, redatelji i glumci, čijom kolaboracijom nastaju filmske uspješnice poput: Bonnie i Clyde (1967.), Diplomac / Graduate (1968.), Goli u sedlu / Easy Rider (1969.), M. A. S. H. (1970.), Posljednja kino predstava / Last Picture Show (1971.) itd.

\section{Prva generacija novoholivuđana - revalorizacija žanrovskoga filma u kontekstu društveno-političke osviještenosti}

Prva generacija novoholivudske struje, pod utjecajem europske kinematografije i subverzivna prikaza intimnih odnosa i kriminalnih radnji, stvara žanrovske filmove (prvenstveno krimić, ratni film i vestern) koje oduševljeno prihvaća publika razočarana vijetnamskim ratom, 
vladajućom elitom i dotadašnjim nekritičkim odnosom prema grijesima američkoga društva.

Bonnie i Clyde, film Arthura Penna, najavio je novi filmski izričaj u američkoj kinematografiji koji je pod utjecajem francuskoga novog vala (Godard, Truffaut) pružio do tada nezamisliv, romantiziran prikaz (brutalna) nasilja protagonista ujedinjenih protiv sustava. Film je nastao $u$ razdoblju kada se Hollywood odmiče od propisanih konvencija i cenzure zadane Produkcijskim kodeksom ${ }^{5}$. Mlađa publika, razočarana u establišment, simpatiziranjem takvih (anti)junaka odmeće se od zadanih ograničenja države/društva. Bonnie $i$ Clyde popularizira subverzivni sadržaj kroz kontekst alijenacije od društva i nasilja nad bezličnim pojedincima koji im stoje na putu. ${ }^{6}$ Prema Joelu Kempsonu, njihov je čin pobune kod mlade, buntovne publike rezultirao empatijom i suosjećanjem u vremenu pogođenom Velikom depresijom. Clydeove i Bonnieine kriminalne radnje odgovor su na društvene restrikcije i financijsku ugrozu, a njihovo se ponašanje sagledava kao avanturistički pokušaj vraćanja slobode koja im je oduzeta. ${ }^{7}$

David Walsh, proučavajući filmografiju Arthura Penna, primjećuje sličnu političku/društvenu angažiranost $u$ njegovim ranijim filmskim djelima, primjerice u filmu Mickey One (1965.), koji je nastao pod utjecajem francuskoga novog vala, dominira osjećaj paranoje i otuđenosti kao refleksije na stanje američkoga društva. Sam redatelj priznaje da je filmska priča inspirirana razdobljem McCarthyjeva žestokog progona komunističkih simpatizera ranih 1960-ih, vremena terora, alijenacije i vječita straha od prokazivanja. Borba za građanska prava i rastući otpor prema institucionalnomu autoritetu prikazani su u filmu Potjera bez milosti / The Chase (1966.) u kojem licemjerje, represija i rasizam

Udruženje filmskih producenata i distributera Amerike (MDPAA) 1930. godine je kodeksom poznatim kao Haysov kodeks (Hays Code) reguliralo filmove prema moralnim/etičkim načelima (cenzuriranjem sadržaja eksplicitna nasilja i prikaza seksualnosti) kako bi bili prikladni za sve dobne skupine.

6 Usp. Joel S. Kempson, „Living with Evil: Crime and Sexuality in Bonnie and Clyde and Chinatown", Inquiries Journal, (2015.), <http://www.inquiriesjournal.com/articles/1011/living-with-evil-crime-and-sexuality-in-bonnie-and-clyde-and-chinatown>, (18. III. 2021.).

7 Isto. 
upravljaju odlukama uglednih teksaških građana. Pennova lijeva politička orijentacija koju nije skrivao ${ }^{8}$ očituje se u prikazu kapitalističkoga društva izgrađena na pohlepi, zbog čega tinjajuće nezadovoljstvo prerasta u nekontrolirano nasilje. Sličan presjek američkoga društva, tj. probleme i napetosti u Sjedinjenim Državama tijekom 1960-ih, uspon hipi pokreta, upotrebu droga, reakciju na Vijetnamski rat i rasne nerede prikazao je jedan od hvaljenijih uradaka, nastao suradnjom Dennisa Hoppera i Petera Fonde, Goli u sedlu.

Stanje društvene krize i opće nesigurnosti na filmsko platno prenijeli su (pod)žanrovi kao što su kriminalistički / politički filmovi, filmovi urote, filmovi katastrofe i sl. Sedamdesete godine obilježene Nixonovom vladavinom donose revolucionarne filmove $u$ kojima se pojedinac bori protiv kriminala i nelogičnih sudskih propisa koji mu onemogućuju djelovanje u skladu sa zakonom. Od kriminalističkih / političkih filmova među važnijima je film Romana Polanskoga Kineska četvrt / Chinatown (1974.), koji se referira na korumpirani kapitalistički sustav kojim drmaju političke afere. Film evocira stanje beznađa i opće pasivnosti podcrtavajući beskorisnost bilo kakva otpora („Forget it, Jake. It’s Chinatown.“9). Chinatown pritom postaje metaforičko mjesto korupcije i nemara u kojem protagonist prekasno shvaća da, unatoč svojoj funkciji i agilnosti, nema nikakva utjecaja na stanje stvari.

Agresivne policajce koji djeluju na rubu zakona u prvi plan postavljaju filmovi Francuska veza / The French Connection (1971.) i Prljavi Harry / Dirty Harry (1971.). Protagonisti ovdje reinterpretiraju zakone kada bivaju suočeni s jakim suparnicima. ${ }^{10}$ Argument za nezakonite i neetične operacije proizlazi iz nemoći društvenih i političkih struktura gdje jedino kontroverzni osobenjak proizvoljno donesenim pravilima može uspostaviti i zadržati sigurnost i red. Osim što kritiziraju

8 „I was quite left politically all through World War II.“ DAVID WALSH, „Arthur Penn, American filmmaker (1922-2010)“, World Socialist Web Site, (8. X. 2010.), <https://www.wsws.org/ en/articles/2010/10/penn-oo8.html>, (13. III. 2021.).

9 Peter Lev, American film of 70 Conflicting visions, University of Texas Press, Austin, 20oo., str. 21.

1o U Francuskoj vezi antagonisti su dileri narkotika, a u Prljavome Harryju riječ je o sociopatu koji ubija iz užitka. 
strukturu policije, ovi filmovi naglašavaju ekstremni individualizam heroja koji, kako bi izvojevao pobjedu, zaobilazi legalnu vlast u okršaju s antagonistima. ${ }^{11}$

Prljavi Harry svojevremeno se našao pod povećalom javnosti kao fašistička propaganda kojom se veličaju cinizam, samovolja i rasistički stavovi središnjega junaka. Harry slijedi vlastiti moralni kompas gazeći građanska prava i ne odgovarajući za svoje postupke, što je posebice istaknuto u slučaju njegova odnosa sa serijskim ubojicom Škorpionom (Scorpio). Antagonist, zamišljen kao aluzija na nikada uhvaćenoga ubojicu Zodiaca, devijantni je karakter koji se opire uhićenju regularnim, zakonskim metodama. Stoga Harryjevi postupci i modus operandi prizivaju stvaranje (anti)junaka koji se od zločinca razlikuje prvenstveno po posjedovanju policijske značke. Ciara Moloney u članku, u kojem piše o interpretaciji Harryjevih postupaka u kontekstu fašističke ideologije, navodi kritičare Rogera Eberta, Pauline Kael i Genea Siskela koji su u filmu vidjeli opasnu usporedbu i pokušaj izjednačavanja predstavnika zakona sa sadističkim ubojicom jer obojica dijele sklonost prema iživljavanju nad žrtvama i proizvoljnim, nekontroliranim izjavama i postupcima. ${ }^{22}$ Don Siegel, redatelj filma, iako zanijekavši da mu je cilj raditi političke filmove, ne skriva svoj liberalni stav i osporavanje institucionalnoga autoriteta ${ }^{13}$ prikazom središnjih junaka odmaknutih od uvriježenih stereotipa i manihejske, crno-bijele karakterizacije. Policajac kao predstavnik zakona istim manipulira do točke gdje ga izravno krši, dok je serijski ubojica izopačeni manijak koji nosi obilježja hipi generacije

${ }^{11} \quad$ Usp. P. LEV, $n$. dj., str. 4.O. - 59.

12 Usp. Ciara Moloney, „Dirty Harry Is and/or Isn't Fascist Propaganda“, The Sundae, (25. II. 2020), <https://thesundae.net/2020/o2/25/dirty-harry-is-and-or-isnt-fascist-propagan$\mathrm{da} />$, (12. III. 2021.).

${ }^{13}$ O tome kako se redatelj smatra buntovnikom koji prezire autoritet piše Peter Flint: „I'm a liberal“, he continued. „I lean to the left, and I don't make political movies. I was telling the story of a hard-nosed cop and a dangerous killer. What my liberal friends did not grasp was that the cop is just as evil in his way as the sniper." „I'm a rebel“, Mr. Siegel told the interviewer. „That's why the young kids like my films. I've been fired from almost every place I've ever worked. I resent authority.“ Peter B. Flint, „Don Siegel, Whose Movies Herald Tough, Cynical Loners, Dies at 78“, The New York Times, (24. IV. 1991.), <https://www.nytimes. $\mathrm{com} / 1991 / 04 / 24 /$ obituaries/don-siegel-whose-movies-herald-tough-cynical-loners-diesat-78.html>, (12. III. 2021.). 
(simbol mira), čime Siegel sugerira da ubojica vjeruje da su mu postupci u skladu s njegovim uvjerenjem. ${ }^{14}$ Sam redatelj, naime, priznaje da je iskazivao sumnju u produkte i značajke određenih društvenih pokreta kao što su egocentričnost i samoživost hipi kulture. ${ }^{15}$

Film Williama Friedkina Francuska veza također prikazuje nasilna, hladnokrvna protagonista, policajca Doylea, koji koristi rasističke uvrede i brutalne metode maltretiranja kojima se, poput Siegelova Harryja, primiče definiciji antijunaka. Kritičar Roger Ebert smatra da je Friedkin kroz karakter Doylea generirao gotovo zastrašujuće jednoumlje i hladnu odlučnost da pobijedi pod svaku cijenu, a njegova patološka psiha nadograđuje uobičajenu priču policijske potjere mačaka i miša. ${ }^{16}$

Sedamdesetih godina jača popularnost filmova urote/paranoje $\mathrm{e}^{17} \mathrm{u}$ kojima se ponovno nameću strahovi od gubitka kontrole političkih i ekonomskih institucija kroz ubojstva, Vijetnamski rat, slučaj Watergate itd. Coppola snima Prisluškivanje / The Conversation (1974.) u kojem progovara o stanju paranoje i tjeskobe kroz slučaj stručnjaka za prisluškivanje kojega, osim osjećaja progonjenosti, muči i moralni aspekt novoga zadatka kao i vlastita interpretacija snimljena sadržaja. Coppola se filmom i motivima (zadiranje u privatnost, špijunaža) referira na aferu Watergate. Vijetnamski rat odgovoran je za psihološke i duševne tegobe mladih Amerikanaca što vjerno predočavaju filmovi poput Coppoline Apokalipse danas / Apocalypse Now (1979.) i sl.

14 Usp. Marc Svetov, „Don Siegel, Film Noir, and politics; The Twists and Turns of a 'Post-Noir Anti-Auteur", Noir City Sentinel, (2009.), <http://www.transatlantichabit.com/ noir/Don-Siegel.pdf>, (10. III. 2021.).

15 Isto.

16 Usp. Roger Ebert, „The French Connection“, RogerEbert.com, (o1. I. 1971.), <https://www. rogerebert.com/reviews/the-french-connection-1971>, (17. IV. 2021.).

${ }_{17}$ Primjeri su takvih filmova: Ubojice i svjedoci / The Parallax View (1974.), Let iznad kukavičjeg gnijezda / One Flew Over the Cuckoo's Nest (1975.), Tri dana kondora / Three Days of the Condor (1975.), Svi predsjednikovi ljudi / All the President's Men (1976.), Lovac na jelene / The Deer Hunter (1978.) itd. 


\section{Druga generacija novoholivuđana - žanrovska heterogenost i razdoblje blockbustera}

Jedno od osnovnih razlikovnih poetičkih obilježja druge generacije novoholivuđana jest usmjerenost na trivijalne žanrove (SF, horor) te, jednim dijelom, povratak klasično narativnoj strukturi i šabloniziranim dramaturškim obrascima, odnosno karakterizaciji likova u formi blockbustera.

Thomas Schatz u članku The New Hollywood navodi da je odustajanje od odlazaka u kino, omiljene američke razbibrige, postao glavni uzročnik teorija o smrti Hollywooda, na što je filmska industrija naposljetku odgovorila generiranjem blockbustera ${ }^{18} .{ }^{19}$ Autor smatra da Novi Hollywood pretpostavlja složene međuigre ekonomskih, estetskih i tehnoloških snaga, o kojima, u konačnici, ovisi uspjeh blockbustera. ${ }^{20}$

Film koji je zabilježio fenomenalan uspjeh kod publike i koji je redefinirao prirodu i financijski potencijal blockbustera jesu Spielbergovove Ralje (Jaws, 1975.). Film je bio popraćen izvanrednom marketinškom kampanjom koja je uvelike pridonijela popularizaciji ovoga pristupa

${ }_{18}$ Ono što podrazumijevamo pod nazivom blockbuster ponešto se mijenjalo duž povijesti filma. Sheldon Hill u članku Rodoslovlje modernog blockbustera navodi dva značenja toga pojma: nešto što ima veliku snagu ili veličinu (osobito epski film ili knjiga) te velika bomba koja može uništiti čitavu četvrt. Usp. SHELdon HALL, „Rodoslovlje modernog blockbustera", Hrvatski filmski ljetopis, Hrvatski filmski savez, Zagreb, god. X. (2004.) br. 40., str. 5 .

19 Usp. Thomas Schatz, „The New Hollywood“, Jim Collins - Ava Preacher Collins Hilary Radner, Film Theory Goes to the Movies: Cultural Analysis of Contemporary Film, Taylor \& Francis Ltd, London, 1993., str. 19. - 24.

2o Schatz u članku The New Hollywood navodi osnovne postavke blockbustera koje pripisuje njegovoj inherentnoj transmedijalnosti; sposobnosti metamorfiziranja u ili iz medijskih produkata poput dječje bajke, stripa, romana, TV-serije ili animiranoga filma. Nadalje, filmska je fabula uglavnom koncipirana tako da njezin sadržaj omogućava nastavak (fenomen franšize). Narativna linija trebala bi se usredotočiti na protagonista i njegovo djelovanje, pri čemu Schatz opisuje glavnoga lika kao samotnjaka koji je gotovo redovito primoran na svojevrsno herojsko interveniranje. Gledatelji bi trebali svjedočiti protagonistovu transformiranju iz relativno nedjelatne, inertne osobe u onu koja preuzima inicijativu i postaje junak dana. Uz napetu i jasnu narativnu strukturu blockbuster zahtijeva i dijametralno okarakterizirana antagonista koji će u nekim slučajevima nastupiti iz superiorne pozicije (fizička, intelektualna nadmoć itd.). Akcijski prizori moraju se izmjenjivati u redovitim intervalima visokoga intenziteta te povremeno ustupiti mjesto drugoj narativnoj liniji koja bi uključivala ljubavnu priču protagonista i njegove odabranice. T. SCHATZ, $n$. dj., str. 32. - 33. 
filmu (film kao spektakl, vizualno i akustički atraktivan). U hibridnoj strukturi Ralja mogu se naći ikonografske oznake i obilježja horora (scene ubojitoga napada morskoga psa i njegovo dijabolično, uvrnuto proganjanje moreplovaca), akcijskoga filma (scene hvatanja morskoga psa) i drame (obiteljski i prijateljski odnosi likova unutar filma). Uspjeh Ralja otvorio je vrata filmovima/autorima kojima su, prema zaključcima kritičara Dragana Juraka, „specijalni efekti i iluzija bili u samoj biti njihove poetike ${ }^{{ }_{21}}$.

Dok je žanr znanstvene fantastike godinama bio eksploatiran kroz hladnoratovske teme o opasnostima neprijatelja izvana (obično kroz motive izvanzemaljaca), Spielberg na tome polju radi preokret filmovima kao što su Bliski susreti treće vrste / Close Encounters of the Third Kind (1977.) i E. T. / E. T. the Extra-Terrestrial (1982.). U njima su misteriozni alieni ilustrirani kao simpatična bića $(E . T)$ ili bar ona spremna na suradnju (Bliski susreti treće vrste). Iste godine kao Bliski susreti, snimljen je i Lucasov hit Ratovi zvijezda / Star Wars koji, baš kao i Spielbergov, potvrđuje nove smjernice u znanstveno-fantastičnome filmu. Ta maštovita Lucasova filmska kreacija galaktička je borba dobrih i zlih sila, svojevrstan spoj intrigantnih karaktera i fantastičnih vizualnih efekata. Ovo je filmsko djelo poznato kao jedno od najkomercijalnijih filmova zabavne industrije, stvorivši pozamašan profit od prodaje igračaka, videoigrica, odjevnih predmeta i raznovrsnih artikala u kućanstvu.

Lucasova poslovna suradnja sa Spielbergom urodila je akcijskim (pustolovnim/ avanturističkim) spektaklom o suvremenome junaku arheologu Indiani Jonesu u filmu Indiana Jones: Otimači izgubljenog kovčega (Indiana Jones and the Raiders of the Lost Ark, 1981.). Serijal o Indiani Jonesu žanrovska je revitalizacija sjajnih avanturističkih filmova s početka dvadesetih do četrdesetih godina (s glumcima poput Douglasa Fairbanksa i Errola Flynna), s inovativnim montažnim postupcima, atraktivnim lokacijama i dozom humorističnosti. Što se tiče aludiranja na povijesni/ideološki kontekst, redatelj radnju smješta u tridesete godine, a kao junakove antagoniste vidi naciste koji otežavaju Indianinu

DrAGAN JURAK, „Igračke, vatromet i postholokaustna televizija“, Kinoteka, Filmoteka 16, Zagreb, god. V. (1993.) br. 44., str. 13. 
potragu za biblijskom arkom (zajedno sa svojim doušnicima, Arapima, koji su i ovdje okarakterizirani kao nepovjerljiv narod). Marković zapaža da se u filmu mogu naći „eksplicitne političke poruke ${ }^{{ }_{22}}$, no motiv koji Spielberg češće eksploatira jest funkcija oca kao zaštitnika obitelji. U redateljevim djelima (Ralje, Bliski susreti treće vrste, E. T., Carstvo sunca / Empire of the Sun, 1987., Jurski park/Jurassic Park, 1993.) primjetna je važnost tradicionalne uloge muškarca/oca obitelji čije djelovanje ima utjecaj na obiteljsku, odnosno, metaforički, društvenu zajednicu.

U kontekstu Spielbergova zagovaranja tradicionalnih vrijednosti (o kojima progovara kroz odgovornost oca, nužnost očuvanja obiteljske zajednice, ulogu djece kao ranjive skupine koja je ignorirana ili odvojena od roditeljske skrbi/zaštite), Marković primjećuje autorovo pozivanje

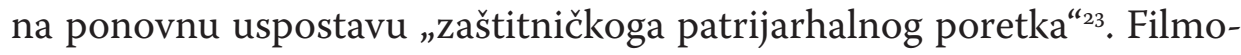
ve ranije faze njegova stvaralaštva obilježava svijet centralne reganovske Amerike s dominantnim konzervativnim građanskim slojem. Redateljeva poetika nalaže antagoniste koji predstavljaju ugrozu na simboličkoj, metafizičkoj razini (svemirci, dinosauri, morski pas). O obnovi obitelji i njezinih vrijednosti te odabiru središnjih junaka i fizičke prijetnje koja ugrožava njihovu, inače vrlo uobičajenu, klišeiziranu egzistenciju, Marković piše:

Koliko god oni imali žanrovske predznake, prvi je film katastrofe npr., dok je drugi SF, oni afirmiraju reganovski novi konzervatizam i ponovnu obnovu tradicionalnih, prvenstveno obiteljskih vrijednosti. No, bitan otklon od starog oblika konzervatizma jest u tipu heroja: za Spielberga je to običan čovjek srednje klase, koji svoj posao shvaća ozbiljno, no sebe ne smatra herojem. Brody, junak filma "Jaws“, te Roy Neary, protagonist „Bliskih susreta treće vrste“, obiteljski su ljudi, predani svom poslu. Ugroženost obitelji ima kataklizmičke korijene (more, svemir, a ne kao prije društvene - gangsteri npr.) i upravo oni moraju obaviti zadatak i tako sačuvati obitelj, ili, u slučaju drugog filma, stvoriti novu. ${ }^{24}$

22 Dario Marković, „Indiana Jones; „Agnus Dei s bičem u ruci“, Kinoteka, Filmoteka 16, Zagreb, god. VI. (1994.) br. 45., str. 22.

${ }^{23}$ Dario Marković, „E.T. Sin i otac“, Kinoteka, Filmoteka 16, Zagreb, god. VI. (1994.) br. 45., str. 27.

24 Isto, str. 25. 
Spielberg i u kasnijim filmskim ostvarenjima koristi slične motive pa autor Igor Tomljanović Jurski park naziva sagom o „stvaranju i odgovornosti za vlastite postupke ${ }^{\omega_{25}}$.

Osim komercijalno uspješna redateljskog tandema Spielberg - Lucas, koji je pokrenuo revoluciju u žanru znanstvene fantastike, taj je žanr proslavio i Johna Miliusa koji je započeo redateljsku karijeru kao već renomirani scenarist, režirajući gangsterski film Dillinger (1973.). ${ }^{26}$ No, ipak je u fantastičnome podžanru mača $i$ magije (sword and sorcery) najviše vidljiv Miliusov doprinos po pitanju oživljavanja trivijalnih žanrova. Miliusova interpretacija junačkih podviga stripovskoga junaka Conana Barbarina iz 1982. (Conan the Barbarian) prati odrastanje Conana i njegovu osvetu nad ubojicom svojih roditelja - čarobnjakom i vođom zmijskoga kulta, Thulsom Doomom. Miliusovo djelo ispunjeno je raznovrsnim vjerskim, političkim i socijalnim referencama, od kojih neke nabraja Dejan Jovović u svojoj analizi filma: „Conan predstavlja zapravo fascinantan spoj magije, biblijskih motiva (Conan razapet na drvetu poput Prometeja i Isusa Krista), tradicionalnih žanrova i Miliusove ideologije o čovjeku kojem je mač njegov najbolji prijatelj. ${ }^{{ }_{27}}$

Osim očite aluzije na kršćanstvo (Conanovo razapinjanje, gigantska zmija), prisutni su i motivi srednjovjekovnih europskih epova u kojima junak isključivo uz pomoć specijalnoga oružja (Conanovo fetišiziranje mača i vjerovanje u njegove moći) uspijeva prevladati najsloženije zadatke. Stalni motiv koji je sveprisutan u filmu jest moć magije i njezina upotreba; vrač hipnotizira svoje podanike upravljajući njihovim mislima i djelima, dok Conanova odabranica iscrtava zaštitne simbole na njegovu tijelu kako bi otjerala zle duhove. Svojstva fantastičnoga pripisuju se i drugim likovima koji su u funkciji Conanovih pomagača (vrač koji mu

25 IgOR TomlJANOvić, „Jurski park“, Kinoteka, Filmoteka 16, Zagreb, god. V. (1993.) br. 44., str. 34 .

26 Film prikazuje posljednje godine Dillingerova života. U prikazu brutalnosti i nasilja, ali i intertekstualno, nadovezuje se na etablirane uspješnice toga žanra poput filma Bonnie $i$ Clyde (o čijim avanturama protagonist čita u dnevnome tisku). Više u: ROGER EBERT, „Dillinger“, RogerEbert.com, (20. XII. 1973.), <https://www.rogerebert.com/reviews/dillinger-1973>, (o6. VIII. 2020.).

${ }_{27}$ Dejan Jovović, „Filmovi desetljeća: Conan“, Kinoteka, Filmoteka 16, Zagreb, god. II. (199o.) br. 19. - 20., str. 34 . 
pomaže zacijeliti rane) ili pak njegovih progonitelja (privlačna djevojka čija se vještičja priroda razotkriva nakon spolnoga čina). Američki, ali i domaći filmski kritičari dugo su lomili koplja oko Schwarzeneggerove uloge, polemizirajući oko primjene Nietzscheova termina übermensch (nadčovjek) u fašističkome smislu. Miliusovov Conan može se iščitati kao djelo koje implementira neke koncepte Nietzscheove filozofije: primjerice, film započinje glasovitom Nietzscheovom izrekom: „Ono što me ne ubije, to me ojača“, a sam protagonist idealan je primjerak fizičke snage (tjelesna isklesanost), nagona za preživljavanjem i nadljudske discipline.

Kritičar Roger Ebert zagovara tezu o Miliusovu koketiranju s fašizmom te je potkrepljuje komentarom o vlastitoj uznemirenosti i nelagodi u prizoru suočavanja nordijskoga nadčovjeka i crnca. ${ }^{28}$ Po toj se tezi Conan prikazuje kao arijevski snagator koji, unatoč svim životnim okolnostima i nedaćama, uspijeva poraziti nadmoćnoga, tamnoputoga vrača čije bi moći trebale daleko nadmašiti Conanove mišiće. S druge strane, Conanova nadmoć usporediva je s ostalim žanrovskim filmovima mača i magije kojima su protagonistov individualizam i superiornost osnovne postavke i koji nemaju fašističke pretenzije. Također, teme iz filma odražavaju političku klimu u SAD-u 1980-ih godina. Budući da Ronald Reagan, tadašnji američki predsjednik, veliča ideale individualizma i patriotizma za vrijeme Hladnoga rata, Conan se može iščitati kao narodni heroj koji se, crpeći snagu iz svojih kušnji i neprilika, obračunava sa svojim tlačiteljima - SSSR-om.

Redatelj Martin Scorsese po svome se kritičkom angažmanu može dovesti u svezu s prvom generacijom novoholivudskih autora. Damir Radić analizira njegov opus s obzirom na kritičku oštricu američkoga društva i politike koja se često pojavljuje u njegovim radovima. Scorseseova kritika američkoga društva indirektno se provlači kroz brojne motive: u Opasnoj djevojci (Boxcar Bertha, 1972.) kritizira sustav koji je dopustio ekonomsku krizu i vlast koja se neljudski obračunava s

${ }_{28}$ Usp. Angela Night, „The Night Shift: Conan The Barbarian, Nietzsche, Philosophy And Fascism", Action a gogo, (26. II. 2017.), <https://actionagogo.com/2017/o2/26/ the-night-shift-conan-the-barbarian-nietzsche-philosophy-and-fascism/> (13. III. 2021.). 
neistomišljenicima; u Taksistu (Taxi Driver, 1976.) može se iščitati kritika korumpiranoga sustava u kojem ratom traumatizirani protagonist svojom rukom nastoji ispraviti društvene devijacije; u filmu New York, New York (1977.) nudi se osuda diskriminativnoga odnosa prema novim strujama u pop-kulturi, dok u filmu U sitne sate / Idiotska noć (After Hours, 1985). pratimo dezorijentirani središnji lik, yuppija, koji sredinu oko sebe smatra prijetnjom. Razjareni bik (Raging Bull, 1980.) vraća se već obrađenu motivu korupcije koja zahvaća protagonistov svijet boksa. I u kasnijim radovima Scorsese iskazuje satiru društva, specifičnu kritičku oštricu iznoseći usput, što vjernije, životni stav i svjetonazor svojih likova. Damir Radić osvrće se na realističnost filmskoga prikaza koja je sveprisutna u Scorsesovim radovima: „Kroz odnos autora prema likovima, kroz nasilje, seks, tjeskobu (posebno izražene u Taksistu, Idiotskoj noći i Posljednjem Kristovom iskušenju), putovanje, mozaičnu strukturu i nostalgiju, Scorsese gradi svoj realistički pristup koji je ishodište njegove poetike. ${ }^{\text {"29 }}$

Scorseseovi likovi jasno su društveno/ideološki određeni s obzirom na redateljevu kritičku angažiranost, što rezimira i Radić koji opisuje jednu skupinu redateljevih likova koje karakterizira „individualnost i borba za neke ideale ${ }^{{ }_{30}}$ :

Ovakav lik (lik sindikalca) u različitim manje ili više modificiranim varijantama, lako je prepoznati u Taksisu (Taxi Driver, 1976) gdje se Travis Bickle (Robert De Niro) sam bori protiv sistema ogrezlog u porok, New York, New Yorku (1977) u kojem jazz saksofonist (De Niro) pokušava nametnuti svoj, tj. crnački, nekonvencionalni improvizacijski stil, ali je nemoćan protiv dominantnog komercijalnog okružja swinga, koji predstavlja sistem, zatim u Razjarenom biku (The Raging Bull, 1980) u kojem Jack La Mota (De Niro) pokušava mimo amoralnih običaja (namještene borbe i sl.) doći do titule prvaka, ali je ipak prisiljen prihvatiti pravila igre. $^{31}$

29 DAmir RAdić, „Martin Scorsese“, Kinoteka, Filmoteka 16, Zagreb, god. II. (1990.) br. 24., str. 20.

30 Isto, str. 17 .

${ }^{31}$ Isto. 
Sljedeći novoholivudski redatelj, Brian de Palma, poznat je po autorskim strategijama, poput podijeljena ekrana (split screen), i različitim tehnikama snimanja (usporeno snimanje, dugi kadrovi, visoki kutovi snimanja itd.) kojima potpisuje svoje filmove i koji njegovim filmovima daju snažan autorski pečat. Douglas Keesey u djelu Brian De Palma's Split-screen navodi da je u ranijim uradcima De Palma stilski bio bliži Godardu (ne skrivajući pretenzije da bi želio postati američki Godard), no kasnijim, dugometražnim filmovima odao je počast Alfredu Hitchcocku i zbog toga često bio prozivan njegovim imitatorom..$^{32}$ Filmom Sestre (Sisters, 1973.) De Palma napušta Godarda i približava se Hitchcockovu stilu mijenjajući žanrove od političke satire do psihološkoga trilera. Sestre su, prvenstveno, hommage Hitchcockovu Psihu (iako se mogu pronaći i reference na Konopac / Rope, 1948., i Prozor u dvorište / Rear Window, 1954., istoga autora) gdje redatelj eksploatira motive opsesije, voajerizma i podvojene ličnosti, citirajući ponekad i fragmente dijaloga iz Psiha. ${ }^{33}$ S idućim filmom, Opsesija (Obsession, 1976.), još jednim trilerom u maniri Hitchcockovih filmova, De Palma istražuje motive opsesivna ponašanja, ljubomore, halucinacije, čak i nekrofilije. Douglas Keesey analizira De Palminu uporabu navedenih motiva koje ponajviše nalazi u Hitchcockovoj Rebeki (Rebecca, 1940.) i Vrtoglavici (Vertigo, 1958.), uspoređujući načine na koje uobličuje i nadograđuje Hitchcockove motive, ne negirajući svoj uzor, nego inkorporirajući ga u vlastitu stilsku poetiku. ${ }^{34}$ De Palmini psihološki trileri usmjereni su na seciranje graničnih kategorija ljudske psihe i popraćeni dramaturškim zavrzlamama i obratima na tragu poznatih filmskih klasika te, samim time, eskapističkoga, postmodernoga predznaka. Problemom negativnoga društvenog djelovanja na pojedinca, koje dovodi do opasnih konzekvenci, bavit će se u idućem žanrovskom uratku pod imenom Carrie (1976.).

32 Douglas Keesey, Brian De Palma's Split-Screen: A Life in Film, University Press of Mississippi, Jackson, 2015., str. 28. -36.

33 Isto.

34 Isto. 
Redatelj će hororom Carrie postići željeni uspjeh i valorizaciju od publike i kritike ${ }^{35}$ te istovremeno postaviti kompleksne odnose unutar obiteljske (majka - kći) i društvene (Carrie - njezini vršnjaci) zajednice koji će definirati tijek radnje. S tinejdžericom telekinetičkih moći koja proživljava traumatično iskustvo na maturalnoj večeri, nakon koje se osvećuje svima koji su je ismijavali i ponižavali (uključujući i vlastitu majku), De Palma pokazuje potencijal i kao redatelj filmova strave. Kritičar Mario Sablić De Palmino djelo smatra jednim od vrsnijih ekranizacija romana Stevena Kinga, a De Palmu režisera koji uspješno širi granice žanrovskog interesa: „Tu su mladenačka fantazija o pravdi i osveti, roditeljska represija, gubitak emocionalne ravnoteže, a sve prožeto atmosferom pritajene strave uz nekoliko briljantno režiranih scena (to se naročito odnosi na veliko finale).“ ${ }^{{ }_{36}}$

Carrie, iako po pitanju psihološke karakterizacije protagonistkinje ponovno eksploatira rubni motiv, također donosi kritiku razornih i represivnih okolnosti koje su generirale psihotičnu osobnost protagonistkinje u završnici filma. Te su okolnosti spoj dviju destruktivnih sila koje potječu iz Carrieina neposrednog okruženja i koje je formiraju u krhku, stidljivu i tjeskobnu djevojku. Riječ je o majčinoj fanatičnoj religioznosti koja na izbezumljenu kći projicira svoj strah od onoga što donosi Carriein ulazak $u$ pubertet te o tome kako je odbacuju i ismijavaju popularne djevojke iz razreda, koje je smatraju zapuštenom, bezličnom i nezanimljivom osobom. Surov i šokantan događaj na pozornici tijekom maturalne večeri Carrie transformira u hladnokrvna egzekutora uslijed čije će frenetične osvetoljubive reakcije stradati i oni koji joj nisu željeli zlo.

Uspjeh filma strave Carrie pokušao je premašiti idućim djelom na temu telekinetičkih sposobnosti tinejdžera - Bijesom (The Fury, 1978.), no film je podbacio. Vrativši se svojim temeljnim preokupacijama - privlačnom ženom kao glavnom junakinjom, motivom ubojstva i podvojene ličnosti, De Palma režira još jedan triler s naglašenom erotskom

Isto.

36 Mario Sablić, „Djelo dostojno prezimena“, Kinoteka, Filmoteka 16, Zagreb, god II. (1990.) br. 22., str. 36 . 
crtom, Obučena da ubije (Dressed to Kill, 1980.). I ovdje je De Palma svjesno posuđivao Hitchcockove motive; oba filma imaju privlačne plavokose protagonistkinje (Angie Dickinson i Janet Leigh), koje su ubijene oštrim predmetima u ranim, najpamtljivijim i najšokantnijim scenama filma, te šizofrene transvestite kao glavne antagoniste koji iznenađuju svojom transformacijom u završnici filmova (Michael Caine i Anthony Perkins).

Njegov neo-noir triler Pucanj nije brisan (Blow out, 1981.) o snimatelju zvuka koji slučajno snimi ubojstvo odgovor je Antonionijevu filmu Povećanje (Blow-Up, 1966.) s razlikom u korištenome mediju. Film nije polučio željene kritike, ponajviše radi neočekivana, tragična završetka, što je De Palmu navelo da se okrene gangsterskomu podžanru u filmu Lice s ožiljkom (Scarface, 1983.). Kriminalistički film o usponu i padu kubanskoga kriminalca Tonyja Montane De Palma je djelomično temeljio na istoimenome filmu Howarda Hawksa iz 1932. U filmu su prikazani Tonyjev uspon od siromašna imigranta do zloglasna gangstera i preprodavača kokaina, njegov moralni pad te, konačno, smrt. De Palmin eksplicitni i hiperbolički prikaz Tonijeva pretjeranog nasilja te seciranje nemilosrdna kriminalnog miljea kokainske scene 8o-ih osigurali su filmu kultni status. Unatoč brojnim filmskim referencama kojima prvenstveno odaje hommage svojim uzorima, De Palma u svakome uratku nadograđuje korištene motive i prikazuje vlastiti autorski stil.

Novoholivudski redatelj John Carpenter, čiji se filmski opus zasniva gotovo isključivo na filmovima strave, paradoksalno, postao je dijelom razvikanih novožanrovskih autora kriminalističkim filmom Napad na policijsku stanicu (Assault on Precinct 13, 1976.). Već je u svome prvom filmskom uratku Carpenter naznačio neizvjesnost (suspens), ali i nadnaravno/patološko zlo kao osnovne sastavnice svojih filmova. Filmolozi Carpenterov film vide kao remake vesterna Rio Bravo (1959.) Howarda Hawksa, koji je smješten u moderni Los Angeles i vizualno vrlo blizak stilu Noći živih mrtvaca (Night of the Living Dead, 1968.) Georgea A. Romera. ${ }^{37}$ Riječ je o šarolikoj skupini ljudi (policajac, policijska službenica,

37 Marco Lanzagorta, "Carpenter, John“, Senses of Cinema, (2003.), <http://sensesofcinema.com/2003/great-directors/carpenter/>, (21. XI. 2020.). 
dvojica zatvorenika) koja se sasvim slučajno zatekla u policijskoj postaji br. 13, gdje je društvo postalo metom napada brutalne bande. Dario Marković u članku Jedan pogled na Ameriku (esej: John Carpenter) uspoređuje Carpenterovo stvaralaštvo s onim njegova idola Howarda Hawksa te primjećuje da Carpenter često oponaša Hawksa u odnosu prema likovima i njihovim moralnim vrijednostima. U slučaju referiranja na film Rio Bravo u djelu Napad na policijsku stanicu Marković opaža srodnost dviju temeljnih situacija, ali i Carpenterovo direktno citiranje Hawksova klasika:

(...) kod Hawksa krv kaplje u kriglu piva na šanku, kod Carpentera krv kaplje po krovu automobila policijske patrole. No, bitno je da i u jednom i drugom slučaju ovi detalji imaju jaku dramaturšku, retoričku funkciju: oni otkrivaju, pokreću radnju, mijenjaju nešto u konstelaciji svijeta $u$ kojem se zbivaju, a kod Carpentera ovaj detalj prerasta u jedan od najvažnijih razriješujućih momenata: nakon toga policija uspijeva locirati mjesto borbe. ${ }^{38}$

U usporedbi s Fordom, Marković navodi sličnosti i razlike filmova Izgubljena patrola (Ford) i Napad na policijsku stanicu (Carpenter). Tako će u oba filma zamijetiti postavljanje nevidljivoga antagonista (kod Carpentera nevidljiva za djelatnike policijske stanice, no ne i za gledatelja kao što je slučaj kod Forda). Carpenterovi negativci nisu samo nevidljivi, nego su i nečujni:

Ono što se čuje samo su posljedice pucanja: razbijeni prozori ili udarci metaka o zidove ili vrata. To i jest razlog koji onemogućuje policijskim patrolama da lociraju sukob. Upravo nečujnost i nevidljivost neprijatelja omogućuje Carpenteru građenje ovog filma. No, nevidljivost neprijatelja, ali isto tako i njegova nečujnost omogućuje da se to zlo shvati kao ono nezdravo, patološko ili nepoznato zlo. Dakle, ono zlo od kojeg čovjeka ne hvata puki strah, već strava i užas. ${ }^{39}$

${ }_{38}$ Dario Marković, „Jedan pogled na Ameriku, esej: John Carpenter“, Kinoteka, Filmoteka 16, Zagreb, god. I. (1989.) br. 9, str. 4.

39 Isto, str. 6. 
Marković uočava Carpenterovo tendiranje prema motivima onostranoga i zastrašujućega, čak i u onim izrazito realističnim djelima. Među ta djela zasigurno spadaju Napad na policijsku stanicu i Netko me promatra (Someone is Watching Me, 1986.), jedini uradci koji ne sadržavaju eksplicitne elemente SF filma ili horora. No, Carpenterova ulična banda u filmu Napad na policijsku stanicu opasno se bliži autorovim uradcima s predznakom nepoznatoga i nadnaravnoga. Banda Cholo vrši neobjašnjiv teror nad malobrojnom skupinom ljudi koja se, većim dijelom, igrom slučaja zatekla u zabačenoj policijskoj postaji. Njihova ustrajnost, neumoljivost i manjak ikakva moralnog osjećaja (smaknuće djevojčice sa sladoledom) djeluju užasavajuće, potpirujući kod gledatelja strah od nepoznatoga (čestu karakteristiku kasnijih filmova): „Utoliko Cholo predstavlja čisto zlo, zlo kao takvo, ono patološko i neprirodno, a takvo zlo karakterizira prije svega horor kakav je npr. Noć vještica. ${ }^{40}$

Carpenterovi se antagonisti krvlju zaklinju na osvetu nakon što policija iz zasjede ubije šestoricu članova bande, no negativci se nemaju namjeru isključivo obračunati s policijskim snagama, nego na nišanu drže i ostale stanovnike losanđeleskoga kvarta kojim patroliraju. Ipak, članovi bande kao pripadnici različitih etničkih skupina ne pritišću okidač na nezaposlene, siromašne i društveno podređene Afroamerikance koje zatječu putom. Prve su im žrtve privilegirani bijelci (prodavač sladoleda, djevojčica), no jednom kada okupiraju policijsku postaju žrtve postaju sve rasne, rodne i društvene skupine. Ono što je eventualno moglo prerasti $u$ društvenu angažiranost $u$ žanru kriminalističkoga filma (policijska brutalnost kod pucanja u leđa članovima bande koji pokušavaju pobjeći, socijalna nejednakost, prikaz Afroamerikanaca kao beskućnika, alkoholičara), Carpenter premješta u sferu horora. Ulična banda postaje apsolutno zlo protiv kojega Carpenterovi junaci imaju šanse jedino ako ostanu hladnokrvni, oprezni i složni, a taj će pristup, u konačnici, osigurati preživljavanje samo nekolicini. Banda postaje simbol patološkoga, nedokučiva zla, što potvrđuje Markovićev komentar:

$40 \quad$ Isto, str. 5 . 
Tema njegovog filma nije priča o uličnoj bandi, njegova tema je strah kao takav, strah od totalno nepoznatog, totalno različitog od nas samih. (...) Carpenterov Cholo tretiran je na isti način na koji je tretirano biće iz svemira u filmu Stvar. Cholo banda je toliko različita od onih i sa strane dobra i sa strane zla, da se za nju može reći „ono“, u obliku one zamjenice koja označava ili nežive ili potpuno nepoznate stvari. ${ }^{41}$

Nagovještaji filma strave u Carpenterovu opusu započinju filmom Noć vještica (Halloween, 1978.), a tematiku mističnoga i sablasnoga Carpenter istražuje u Magli (The Fog, 1980.), Stvoru (The Thing, 1982.), Cristine (1983.), Oni žive (They Live, 1988.) itd. Noć vještica Marković dovodi u vezu s Hitchcockovim Psihom (1960.) i to podrobno argumentira filmskim primjerima dvojice redatelja. Dok je kod Hitchcocka žena postala žrtvom psihopata bježeći pred policijom i tražeći sklonište u izoliranome hotelu („Narodski rečeno, skrenula je s pravog puta i to je platila glavom. Moralno i poučno. “42), u Carpentera manijak Michael Myers, koji vreba američkim susjedstvom u Noći vještica, također traži žrtve (srednjoškolke) koje „nepromišljeno i lakomisleno“" ${ }^{43}$ koriste „odsutnost nekog kontrolnog organa ili tijela: roditelja ili pak poslodavca" ${ }^{44} .45$

Carpenter u Noći vještica upozorava na važnost osjećaja straha i nužnost odgovorna ponašanja. Djevojke koje su odlučile izbjegavati svoju odgovornost (čuvanje mlađe braće/sestara), pritom se izrugujući protagonistkinji koja svoje obveze shvaća ozbiljno, bivaju kažnjene nakon što im antagonist utvrdi krivicu. Myersova identifikacija s mlađim bratom protagonistkinje evocira sjećanje na vlastito djetinjstvo obilježeno njegovim prvim ubojstvom, „kažnjavanjem“ sestre za identičan propust u večeri kada se, umjesto brige za brata, prepustila intimnomu druženju s mladićem. Lik Michaela Myersa u kontekstu moralne odgovornosti predstavlja opomenu, koja se, posljedično, manifestira u kažnjavanje

41 Isto.

42 Isto, str. 7.

43 Isto.

44 Isto.

45 Kao i u Psihu, i kod Carpentera stradavaju djevojke koje olako shvaćaju svoju odgovornost (čuvanje djece) i iskradaju se kako bi provodile noći sa svojim mladićima. Djevojka koja je pošteđena jest upravo ona koja je pokrivala njihove propuste i preuzimala na sebe njihove obveze. 
određenih pojedinaca koji tu odgovornost ignoriraju. Vrlo se slične implikacije mogu naći u Napadu na policijsku stanicu. U oba filma antagonisti djeluju naglo, brutalno i vrlo ustrajno u svome cilju eliminiranja određene skupine ljudi koja je potpuno nesvjesna opasnosti i povoda takve akcije. Dok su u Noći vještica u opasnosti djevojke koje su odbile preuzeti roditeljsku ulogu, obraniti i zaštititi svoje mlađe članove obitelji (kao što to pravovremeno i dosljedno čini protagonistkinja), tako i u Napadu stradavaju oni koji su potpuno nesvjesni opasnosti (djevojčica koja želi kupiti sladoled), odnosno koji ignoriraju znakove koji upućuju na kriznu situaciju (policajci koji ne uspijevaju primijetiti regrutiranje članova opasne bande).

Marković pojašnjava kako se „zlo pojavljuje kao kazna, ali globalna kazna, koja nije vezana sa slučajem, tj. zločinom ili nemoralom pojedinca, već određene društvene sredine ${ }^{{ }^{4} 6}$. Carpenterovi junaci moraju pokazati osobine koje će ih očuvati na životu (svjesnost opasnosti, snalažljivost, samostalnost, hrabrost), pri čemu nerijetko djeluju individualno, što kritičara Dejana Jovovića dovodi do zaključka da je ključni motiv njegovih filmova ljudska otuđenost. ${ }^{47}$ Takav odnos prema antagonistu (simbol zla) i protagonistima (odabranomu pojedincu / skupini ljudi koja posjeduje osobine potrebne za preživljavanje) jasan je i u filmu strave Stvor. I u tome filmu nekoherentna i nehomogena skupina Amerikanaca, u po život opasnoj situaciji, izražava sumnju i međusobno nepovjerenje, zbog čega stradavaju svi članovi družine, osim dvojca koji, bar privremeno, udružuje snage u borbi protiv izvanzemaljskoga stvora. ${ }^{48}$

Društveno-političke konotacije mogu se naći u Carpenterovim filmovima poput Bijega iz New Yorka / Escape from New York (1981.) i Oni žive / They Live (1988.), koji nude ciničan pogled na razdoblje Reaganove vladavine i političke korupcije iz perspektive običnih građana,

$46 \quad$ Isto.

47 Dejan Jovović, „Filmovi desetljeća: Stvor“, Kinoteka, Filmoteka 16, Zagreb, god. II. (1990.) br. 19. - 20., str. 47 .

48 Ovako Jovović analizira Carpenterove središnje likove: „Dolaze do izražaja egoizam, strah i netrpeljivost, i svaki pokušaj zajedništva brzo propada, te će dvoboj sa 'stvorom' preživjeti samo najveći individualci.“ D. Jovović, „Filmovi desetljeća“, str. 47. 
odnosno radničke klase društva. ${ }^{49}$ Oni žive jedna je od najboljih antikapitalističkih satira ${ }^{50}$, prema Ciari Moloney, u kojoj protagonist pomoću specijalnih sunčanih naočala spoznaje istinu o neljudskim, zastrašujućim stvorenjima koja se razotkrivaju kao vladajuća, najbogatija i najmoćnija društvena struktura. Borba protiv superiorne izvanzemaljske rase koja manipulira ljudima postaje još više neizvjesna kada središnji junaci shvate da pohlepna i korumpirana ljudska rasa surađuje s njima.

Uz imena druge generacije novoholivudskih redatelja veže se i Walter Hill kojega je Dejan Jovović istaknuo kao jednoga od rijetkih američkih režisera koji su uspjeli postići kultni status kod hrvatskih gledatelja. Usprkos ignoriranju kritike (koja mu je zamjerala nedovoljnu tematsku angažiranost), njegovo je ime domaćoj publici bilo dovoljan mamac za odlazak u kino. ${ }^{51}$ Hillovi akcijski filmovi (koji su žanrovski najdominantniji) dokazuju njegovu superiornost u režiranju akcijskih scena. Vozač (The Driver, 1978.) prikazuje automobilske jurnjave dvojice suparnika (vozača i policajca) koji tijekom filma, jednako superiorno pozicionirani, iskušavaju i nadmudruju jedan drugoga. Njegovi Ratnici podzemlja (The Warriors, 1979.) tematski se bave obračunima mladih unutar podzemlja velikih gradova. U izrazito naturalističnome prikazu supkulture mladih odmetnici od zakona dijele se na grupaciju dobrih i loših (po uzoru na tipično obilježje američkih vesterna). Gledatelj se instinktivno postavlja na stranu pozitivne bande i emocionalno angažira zahvaljujući Hillovoj zanimljivoj uporabi motiva krivo optuženoga..$^{2}$ Njime se apostrofiraju odlike grupe (zajedništvo, žrtva, upornost, hrabrost) uz pomoć kojih će skupina u konačnici izbjeći nesretnu sudbinu. Južnjačka utjeha (Southern Comfort, 1980.) predstavlja Hillovu političku i društvenu angažiranost (podtekst Vijetnamskoga rata) kao i izravno citiranje Johna Forda (Izgubljena patrola / The Lost Patrol, 1934.). Hillovi Jahači

49 Usp. Ryan Lambie, „John Carpenter: Analyzing His Style and Growing Influence“, Den of Geek, (16. I. 2019), <https://www.denofgeek.com/movies/john-carpenter-analyzing-hisstyle-and-growing-influence/>, (12. IV. 2021.).

50 Usp. C. MOlOney, $n$. dj.

${ }^{51}$ Dejan Jovović, „Posljednji pravi kauboj: Walter Hill“, Kinoteka, Filmoteka 16, Zagreb, god. II. (1990.) br. 23., str. 16. - 22.

${ }^{52}$ Usp. isto. 
na duge staze (The Long Riders, 1980.) posveta su nenadmašnim redateljima vesterna, Samu Peckinpahu i Johnu Fordu. U središtu Hillova zanimanja ponovno je grupacija odmetnika, pljačkaša banaka koji su, kao i u prethodnim autorovim ostvarajima, prikazani sa simpatijama. Redatelj poseže za prikazom intimnoga života njegovih protagonista (družina Jesseja Jamesa) u kojima svjedočimo jednoj toploj, gotovo romantiziranoj slici njihovih života. O Hillovu doprinosu žanru vesterna, od 8o-ih godina pa nadalje, piše Tomislav Čegir koji donosi sažet prikaz svih akcijskih filmova Waltera Hilla, koji se mogu protumačiti u kontekstu žanra vesterna s kojim dijele dominantne motive i karakterizaciju likova ${ }^{53}$ :

'Svaki je film koji sam snimio bio vestern', poznata je tvrdnja Waltera Hilla, a možemo je potkrijepiti razmatranjem struktura svakoga od naslova opusa. Jer u Hillovim filmovima zatječemo situaciju bezakonja ili pak nedostatka ispravnih zakona u kojima junak individualizmom i moralnim nazorima uspijeva ispraviti narušenu ravnotežu, a upravo je to kontekst vesterna. Pritom ne treba zaboraviti da je Hill, uz Clinta Eastwooda, jedini redatelj koji je u proteklih nekoliko desetljeća vestern održavao relevantnim žanrom. ${ }^{54}$

Hillovi akcijski/vestern junaci također posjeduju karakteristike koje ih izdvajaju od ostatka društva, a koje ukazuju na to da i Hillov fikcionalni

53 Čegir ovako sažima Hillova djela: „Jahači na duge staze postmodernističko je sagledavanje povijesnoga odmetnika Jesseja Jamesa i njegove bande, stilski postavljen u krajnostima uzora od Sama Peckinpaha do Johna Forda i izniman je doseg u odvojcima odmetničkoga u vesternu. Geronimo (1993) je pak nasljednik tradicije konjaničkoga vesterna, strukturom nalik Udaljenoj trubi (Raoul Walsh, 1964). Unatoč razvidnim kvalitetama, taj je film ostao zanemaren u trenutku nastanka i, usprkos povremenim naznakama, još nije dosegnuo potpuniju revalorizaciju. Divlji Bill (1995) revizionističko je sagledavanje života glasovitoga revolveraša Divljeg Billa Hickoka, koje ipak odražava dekadenciju Hillova stila. Hillov značenje u okvirima žanra potvrđeno je izborom za redatelja pilot-epizode (2004) televizijskoga vestern-serijala Deadwood, a kvaliteta dvodijelnim televizijskim filmom Put iskupljenja (2006). Premda bi mjestimično sažimanje građe pridonijelo višem intenzitetu, Put iskupljenja elegičan je osvrt spram Divljega zapada i iznimno djelo koje možemo uvrstiti u vrhunce žanra u novijim razdobljima.“ ToMISLAV ČEGIR, „Američki filmski postmodernist“, Vijenac, (o4. IV. 2013.), <http://www.matica.hr/vijenac/498/Ameri\%C4\%8Dki\%2ofilmski\%20 postmodernist/> (10. X. 2020.).

${ }_{54}$ Isto. 
svijet uvjetuje specifičnu unutarnju karakterizaciju likova koja im omogućava golo preživljavanje u surovoj okolini. Jovović o likovima unutar Hillova opusa govori kao o junacima koji su „čvrsto usmjereni svom cilju, često vrlo škrti na riječima, visokih moralnih kvaliteta i okrenuti sami sebi, odnosno pouzdani samo u svoje vlastite sposobnosti“ ${ }^{\text {“5 }}$.

Kao i kod ostalih predstavnika novoholivudskoga vala, i kod Hilla su jasno izraženi prirodna sklonost vodstvu, pravičnost, heroizam i individualizam glavnih junaka nasuprot slabim, bojažljivim, arogantnim ili labilnim likovima. Primjerice, u filmu Južnjačka utjeha nekolicina lakomislenih i bahatih vojnika na vježbi u močvarnome području izazove na čitavu skupinu bijes domorodaca, Kajuna, koji ih nemilice progone eliminirajući jednoga po jednoga. Razjedinjena skupina nastrada, svatko pojedinačno radi svoga grijeha, a opstaju oni koji, unatoč općoj paranoji, strahu i dezorijentiranosti, pokazuju potreban instinkt za preživljavanjem. Upravo kod Južnjačke utjehe Jovović potvrđuje one osobine po kojima su Hillovi junaci jedinstveni: „Hill grupu predstavlja kao mikrokozmos populacije Amerike i nije neobično da će iz takve grupe opstati samo oni koji posjeduju sve osobine prijašnjih Hillovih junaka (strogi individualizam, šutljivost, snalažljivost, inteligencija)." ${ }^{56}$

Hill u Južnjačkoj utjesi koristi motive slične onima koje je istraživao Carpenter u Napadu. Zajedničko im je polazište lik antagonista, nevidljivih napadača koji predstavljaju apsolutno zlo te negostoljubiva i/ili nepoznata sredina koja im otežava snalaženje i obranu. Obje bi napadnute skupine (policajci, vojnici) trebale biti obučene za slične izvanredne okolnosti te imati prednost pred neformalnom, nekonzistentnom i nehomogenom skupinom. Ipak, u oba će se filma pokazati da je upravo individualno i bahato djelovanje pojedinaca unutar grupe krivac za slabosti skupine i pojedinačne pogibelji. $S$ jedne strane imamo razjedinjenu skupinu te paranoične pojedince koji pokazuju najgore osobine gonjeni strahom za vlastitu egzistenciju, a s druge strane vidimo prisebnost, pravednost i hrabrost onih koji će preživjeti.

D. Jovović, „Posljednji pravi kauboj“, str. 17.

Isto, str. 18. 


\title{
Zaključak
}

Unatoč raznolikosti u odabiru, pristupu i obradi žanra, novoholivudski filmovi, koji se javljaju kao odgovor na društvene i političke mijene u Americi, polaze od istoga ishodišta - želje za popularizacijom i komercijalizacijom filma kroz povratak žanru. Dario Marković u eseju o stvaralaštvu Johna Carpentera ističe da autori nisu imali jedinstvenu poetiku, no bili su ujedinjeni u zajedničkome pothvatu - revalorizaciji više ili manje marginaliziranih žanrova preko kojih su uspjeli prenijeti određenu društvenu/političku kritiku ili vlastiti ideološki stav:

\begin{abstract}
Naime, autori tzv. novog Hollywooda, za razliku od starih majstora, ipak nisu uspjeli formirati jasno i precizno svoje stavove, koji bi se najjednostavnije mogli definirati kao odnosi prema svijetu u kojem žive. Utoliko se i svaki pojedini film, ma koliko bio dominantno žanrovski usmjeren, ipak može promatrati i kao svojevrsni sukob između onog manifestnog, što samo na prvi pogled globalno određuje film i onog latentnog koje to manifestno u određenoj dozi negira. Jednostavnije rečeno, radi se o pokušaju prevladavanja tradicionalnih žanrova i to upravo pomoću latentnih filmskih simbola koji onda često sadrže vrlo globalu poruku. ${ }^{57}$
\end{abstract}

Poetički stil i politički stav kod starije se generacije novoholivudskih redatelja očituje $\mathrm{u}$ inkorporiranju koncepcije novovalovskih autora $\mathrm{u}$ žanrovska djela koja će progovarati o društvenim ili političkim aspektima tadašnje Amerike. Agresivni i apatični protagonisti, borba protiv institucija, oslobođenje od stega društva, bezakonje - sve su ovo dramaturški elementi koje možemo naći u najzvučnijim predstavnicima ovoga pokreta, među kojima su i filmovi Arthura Penna Bonnie i Clyde i Dona Siegela Prljavi Harry. Oba filma, naime, donose srodan prikaz bunta i kontroverzna ponašanja središnjih likova, iako oni djeluju sa suprotne strane zakona. Bonnie i Clyde u ulogama kriminalaca i ubojica te Harry u ulozi policajca djeluju jednako subverzivno kada uzimaju pravdu u svoje ruke i dijele je prema vlastitomu nahođenju.

$\mathrm{S}$ druge strane, $\mathrm{u}$ filmovima mlađe generacije redatelja javljaju se eksploatacijski i trivijalni žanrovi (horor, znanstvena fantastika, film

57 D. MARKović, „Jedan pogled na Ameriku“, str. 4. 
katastrofe) koji su unutar eskapističkoga, žanrovskoga filma prenijeli latentne poruke o odgovornosti i ulozi pojedinca. Primjerice, Carpenterova Noć vještica i De Palmina Carrie ne dijele samo sklonost žanru horora, nego i zajedničke motive tinejdžerske neobuzdanosti, bahatosti i samoživosti (u likovima sporednih djevojaka) koji ih, u konačnici, koštaju života. Carpenterov psihotični manijak i De Palmina Carrie dijele i osnovni dramaturški pokretač - poriv za osvetom koju će iskaliti i na vlastitoj obitelji. Mayers, obilježen scenom iz djetinjstva, kada je ostavljen na brigu starijoj sestri koja je svoju ulogu u potpunosti zanemarila, kreće u ubilački pohod obilježen upravo tom epizodom te za prvu žrtvu odabire vlastitu sestru. Carrie je također traumatizirana bolesnom opsesijom vlastite majke koja je upozorava da će na maturalnoj večeri biti ismijana i ponižena. Kada se pokaže da je majka bila u pravu, taj trenutak djeluje kao okidač nakon kojega Carrie vrši osvetu nad čitavom generacijom maturanata, ali i nad vlastitom majkom.

\section{Literatura}

- Čegir, Tomislav, „Američki filmski postmodernist“, Vijenac, (04. IV. 2013.), http://www.matica.hr/vijenac/498/Ameri\%C4\%8Dki\%20filmski\%20postmodernist/, (10. X. 2020.).

- Ebert, Roger, „The French Connection“, RogerEbert.com, (01. I. 1971.), <https://www.rogerebert.com/reviews/the-french-connection-1971>, (17. IV. 2021.).

- Flint, Peter B., „Don Siegel, Whose Movies Herald Tough, Cynical Loners, Dies at 78“, The New York Times, (24. IV. 1991.), <https://www.nytimes.com/1991/04/24/obituaries/don-siegel-whose-movies-herald-tough-cynical-loners-dies-at-78.html>, (12. III. 2021.).

- Hall, Sheldon, „Rodoslovlje modernog blockbustera“, Hrvatski filmski ljetopis, Hrvatski filmski savez, Zagreb, god. X. (2004.) br. 40., str. 5. - 15. 
- Jovović, Dejan, „Filmovi desetljeća: Stvor“, Kinoteka, Filmoteka 16, Zagreb, god. II. (1990.) br. 19. - 20., str. 47.

- Jovović, Dejan, „Filmovi desetljeća: Conan“, Kinoteka, Filmoteka 16, Zagreb, god. II. (1990.) br. 19. - 20., str. 34.

- Jovović, Dejan, „Posljednji pravi kauboj: Walter Hill“, Kinoteka, Filmoteka 16, Zagreb, god. II. (1990.) br. 23., str. 16. - 22.

- JURAK, DRAGAN, „Igračke, vatromet i postholokaustna televizija“, Kinoteka, Filmoteka 16, Zagreb, god. V. (1993.) br. 44., str. 13. - 16.

- Keesey, Douglas, Brian De Palma's Split-Screen: A Life in Film, University Press of Mississippi, Jackson, 2015.

- Kempson, Joel S., „Living with Evil: Crime and Sexuality in Bonnie and Clyde and Chinatown“, Inquiries Journal, (2015.), $<$ http://www.inquiriesjournal.com/articles/1011/living-with-evilcrime-and-sexuality-in-bonnie-and-clyde-and-chinatown>, (18. III. 2021.).

- LAmbie, Ryan, „John Carpenter: Analyzing His Style and Growing Influence“, Den of Geek, (16. I. 2019), <https://www.denofgeek. $\mathrm{com} / \mathrm{movies} /$ john-carpenter-analyzing-his-style-and-growinginfluence/>, (12. IV. 2021.).

- Lanzagorta, Marco, "Carpenter, John“, Senses of Cinema, (2003.), <http://sensesofcinema.com/2003/great-directors/carpenter/>, (21. XI. 2020.).

- Lev, Peter, American film of 70 Conflicting visions, University of Texas Press, Austin, 2000.

- Marković, Dario, „E.T. Sin i otac“, Kinoteka, Filmoteka 16, Zagreb, god. VI. (1994.) br. 45., str. 25. - 27.

- Marković, Dario, „Indiana Jones; „Agnus Dei s bičem u ruci“, Kinoteka, Filmoteka 16, Zagreb, god. VI. (1994.) br. 45., str. 22. 24. 
- Marković, Dario, „Jedan pogled na Ameriku, esej: John Carpenter", Kinoteka, Zagreb, Filmoteka 16, god. I. (1989.) br. 9., str. 4. -10 .

- Mclean, Duncan, „The Evolution of the term 'New Hollywood”, Macquarie University, (9. X. 2009.), <http://www.researchonline. mq.edu.au/vital/access/manager/Repository/mq:10597;jsessionid=B7A79438581650E3A50998AA4DD3A72A?f0=sm_creator\%3A\%22McLean\%2C+Duncan\%22>, (23. X. 2020.).

- Moloney, Ciara, „Dirty Harry Is and/or Isn't Fascist Propaganda", The Sundae, (25. II. 2020), <https://thesundae.net/2020/02/25/ dirty-harry-is-and-or-isnt-fascist-propaganda/>, (12. III. 2021.).

- Night, Angela, „The Night Shift: Conan The Barbarian, Nietzsche, Philosophy And Fascism", Action a gogo, (26. II. 2017.), <https:// actionagogo.com/2017/02/26/the-night-shift-conan-the-barbarian-nietzsche-philosophy-and-fascism/>, (13. III. 2021.).

- RAdić, DAmir, „Martin Scorsese“, Kinoteka, Filmoteka 16, Zagreb, god. II. (1990.) br. 24., str. 15. - 21.

- SAblić, Mario, „Djelo dostojno prezimena“, Kinoteka, Zagreb, Filmoteka 16, god. II. (1990.) br. 22., str. 34. - 39.

- Schatz, Thomas, „The New Hollywood“, Collins, Jim - PreaCher Collins, Ava - Hilary Radner, Film Theory Goes to the Movies: Cultural Analysis of Contemporary Film, Taylor \& Francis Ltd, London, 1993.

- Svetov, Marc, „Don Siegel, Film Noir, And Politics; The Twists and Turns of a 'Post-Noir Anti-Auteur', Noir City Sentinel, (2009.), $<$ http://www.transatlantichabit.com/noir/Don-Siegel.pdf >, (10. III. 2021.).

- Tomljanović, Igor, „Jurski park“, Kinoteka, Filmoteka 16, Zagreb, god. V. (1993.) br. 44., str. 34. - 35.

- Walsh, DAVID, „Arthur Penn, American filmmaker (1922-2010)“, World Socialist Web Site, (8. X. 2010.), <https://www.wsws.org/en/ articles/2010/10/penn-o08.html $>$, (13. III. 2021.). 
Review article

Received on November 24, 2020

Accepted on April 20, 2021

JELENA Grgić

\section{NEW HOLLYWOOD - SOCIOPOLITICAL CONTEXT AND GENRE ASPECT}

\section{Abstract}

The paper includes an overview of New Hollywood directors and their films, as well as the sociopolitical context and changes in the American way of life that preceded the arrival of the so-called blockbusters, i.e. new genre films. The paper will discuss a new approach to the genre film by a generation of educated directors who will successfully renew genre in their works and, in some cases, make sequels in the form of (even today very popular) franchise. The analysis of some works made by a younger and partly older generation will show their relation to social and political circumstances, revitalization of marginalized genres, as well as stylistic features such as: intertextuality, citations, pastiche, homage (dedication), etc.

Keywords: New Hollywood; blockbuster; homage; genre; political and social context; American cinematography 